Chapter Title: The implications of Brexit for the future of Europe

Chapter Author(s): Michelle Cini and Amy Verdun

Book Title: Brexit and Beyond

Book Subtitle: Rethinking the Futures of Europe

Book Editor(s): Benjamin Martill, Uta Staiger

Published by: UCL Press. (2018)

Stable URL: https://www.jstor.org/stable/j.ctt20krxf8.12

JSTOR is a not-for-profit service that helps scholars, researchers, and students discover, use, and build upon a wide range of content in a trusted digital archive. We use information technology and tools to increase productivity and facilitate new forms of scholarship. For more information about JSTOR, please contact support@jstor.org.

Your use of the JSTOR archive indicates your acceptance of the Terms \& Conditions of Use, available at https://about.jstor.org/terms

This book is licensed under a Creative Commons Attribution 4.0 International. To view a copy of this license, visit http://creativecommons.org/licenses/by/4.0/.

UCL Press is collaborating with JSTOR to digitize, preserve and extend access to Brexit and Beyond 


\section{6 \\ The implications of Brexit for the future of Europe}

Michelle Cini and Amy verdun

\section{Introduction}

The result of the UK's referendum on EU membership came as a shock not only to UK elites, but also to the rest of the EU. The outcome hit the EU, its Member States and its institutions, hard for many reasons - but perhaps for three in particular. First, it was the first time (barring the exceptional cases of Greenland and Algeria, for which see Kiran Klaus Patel's Chapter 12 in this volume) that the EU would diminish in size. Second, EU actors recognised that the political implications of the UK's decision would reverberate across their domestic political arenas. Third, the outcome was extremely puzzling. Few could figure out exactly why UK voters wished to leave, why the UK government would accept the decision when there was such a slim majority in favour of leaving, why the popular support was against what most experts and leading politicians advocated for, and what the UK would put in its place. Furthermore, the referendum results varied significantly across the UK, suggesting that any new relationship the UK might end up having with the EU (what became known as a 'soft' or a 'hard' British exit from the EU) could alter the UK's constitutional settlement. Despite numerous concerns about how the UK and the EU would sort through the many issues involved in only two years, Prime Minister Theresa May invoked Article 50 on 29 March 2017 by notifying the EU Council President Donald Tusk of the UK's intention to leave the EU (HM Government 2017b). 
While the domestic debate on Brexit has mainly focused on the implications for the UK, it is important to reflect on the possible implications of Brexit for European integration more generally. The challenge comes from the fact that Brexit is not 'the only game in town', but rather one of several 'crises' that have been ailing the EU, and which will also affect European integration (Cini \& Pérez-Solórzano 2016; Nugent, Chapter 5 in this volume). As such, Brexit has to be considered as part of a broader package of uncertainties determining the direction of travel for the EU. On that basis, we view successive EU crises (e.g. the eurozone crisis, the migration crisis, and the crisis associated with Brexit) as contextual factors that open windows of opportunity and generate sources of motivation for actors who seek to take advantage of the instability and uncertainty that crisis provokes. They do this by pushing their own agendas. These agendas, whether or not they deal explicitly with European integration, have repercussions for the EU. These repercussions are not so much final outcomes as processes of change: they either fragment the EU or make it more cohesive. With that in mind, in addressing the possible impact of Brexit on European integration, we distil two broad trajectories, the first of which leads to the fragmentation and weakening of the EU (the centrifugal trajectory); and the second, which leads to greater EU cooperation, and the strengthening of the European integration process (the centripetal trajectory).

\section{The UK: an influential EU Member State}

The premise on which the argument rests is that the UK has been, until now, an influential member of the EU. Ever since joining, in 1973, what was then the European Communities, the UK, as one of the larger Member States, has more than most helped to shape European integration. It has done so in two ways: first, by constraining EU initiatives; and second, by supporting and promoting EU initiatives.

In its constraining role, the UK often sought to veto or limit EU initiatives. An example of such behaviour can be found in the negotiations on the Maastricht Treaty. These negotiations led to the creation of the EU with its important new policy of EMU and its Social Chapter. The UK managed to restrict integration in these areas and eventually negotiated special arrangements for itself in both cases (but only having first made sure they were restricted in their scope and not overly 'federal') (Verdun 2000). More recently, the UK exerted its veto against the reform of the Lisbon Treaty. Other Member States were keen to strengthen the 
rules on budgetary and fiscal governance, in the light of the eurozone crisis, so as to firm up the Stability and Growth Pact (SGP). As there was no unanimous agreement on the matter, the other Member States signed the Treaty on Stability, Cooperation and Governance (often known as the 'Fiscal Compact') as an intergovernmental treaty in 2012, which subsequently came into effect in 2013.

The UK has not always been successful in its attempts to limit EU initiatives, however. As UK Prime Minister Thatcher discovered in the early 1980s, for example, the national veto, preventing the operation of qualified majority voting, was already something of a chimera. To this day, more often than not, the Council takes decisions by consensus. On those occasions when the Council actually votes, in the vast majority of cases the UK votes with the majority. Having said that, recent research by Simon Hix and Sara Hagemann suggests that this situation has recently changed. Their research on formal voting outcomes shows that although the UK failed to vote the same way as the winning vote in only 2.6 per cent of the cases in the period 2004-9, in the more recent period (2009-15) it was deviating from the winning vote in 12.3 per cent of cases (Hix \& Hagemann 2015).

Second, in its supportive role, the UK itself promoted various initiatives, from the introduction of regional and cohesion policy in the 1970s, to the relaunch of the internal/Single Market in the 1980s, and even, though it ultimately never became a full member, the design of the architecture for EMU and Justice and Home Affairs. It also was often an advocate of 'widening' over 'deepening', that is, in favour of expanding the EU, so as to include new Member States, rather than supportive of deeper integration in the areas in which the EU was already involved. Its policy influence is perhaps most clearly identified in the UK's shaping of Enlargement Policy and in its impact on Common Security and Defence Policy, where the UK became a core EU player - not least because of the size of its armed forces and defence sector.

Successive UK governments have thus been fairly successful in shaping EU initiatives in line with what they conceive to be in the national interest. Of course, there are many instances where 'red lines' were crossed and compromises agreed - even if they were not always presented as such back home. Standing back from the specifics, the UK's influence has promoted, first, a particular form of European integration, and second, a particular ideological agenda. In the case of the former, UK governments have tended, more than other governments, to favour intergovernmental solutions to institutional reform. The instigation of 
the pillar system at Maastricht, which failed to integrate internal affairs and foreign policy into the EU's supranational 'European Community' pillar, is a notable case in point. With regards to the latter point, UK governments have advocated a more liberal economic agenda within the EU, irrespective of the party in power.

\section{The impact of Brexit}

Based on the premise that the UK has been an influential Member State of the EU, what then might be the implications of UK withdrawal for European integration? While the two perspectives - a centrifugal and a centripetal one - oversimplify the options available, and do not cover all potential implications, they do serve as a useful heuristic device in highlighting the ways in which Brexit might be used by different actors to advance their own political agendas on the future of Europe.

\section{The centrifugal trajectory}

Arguably, the EU has never been more fragmented than it is today. Divisions over policy preferences have become bitter. European solidarity has been undermined as a consequence of both long-term problems and more recent crises. Growing distrust of European elites has been exploited by nativist groups and parties, often allied with anti-immigration sentiment, to propose populist solutions to Europe's problems. Euroscepticism has sometimes driven these agendas, though on other occasions it has simply become a supplementary agenda. Important substantive policy differences often lie at the source of these divisions. The political cleavage that opened up during the eurozone crisis, based on an economic split between creditor states, such as Germany, and debtor states, such as Greece, saw the countries directly involved in the crisis take opposite sides in a bitter blame-game. A similar phenomenon was witnessed at the height of the migrant crisis, where the absence of effective burdensharing exacerbated already fragile relations between North and South, and between East and West. The citizens and governments of numerous Member States began to disengage from European integration, turning in on themselves. Collective institutions, such as the border-free Schengen system, were suspended, ostensibly for a limited time, but flagging up the possibility of total collapse. While policy differences may be resolved once solutions are found and the crisis passed - the more fundamental differences that shape them, differences in assumptions about social 
and economic liberalism, whether from the left or the right, seem more intractable.

Where does Brexit and the UK fit into this analysis of the EU? It is paradoxical that the UK was always on the outside of these issues. It looked on while the crises were in full flow. But these high-profile crises hide the fact that where the more pro-European governments of the EU, perhaps supported by a Franco-German vanguard, would be inclined to seek deepened integration (as in areas such as fiscal policy, police cooperation, and immigration and border control), the UK was typically the voice providing opposition and scepticism, and advocating greater caution. Although there were occasions when the UK was in a minority of one, it was often speaking out loud the private thoughts of other Member States. Where Central and Eastern European governments were reluctant to appear anti-European, they were often content with the UK's more subdued vision of integration. With this voice gone, others will have to take over this role, and their vision will be a different one than the liberal-market-oriented, Atlanticist view that the UK typically represented. These other states, moreover, do not have the same political clout that the UK managed to conjure up - the product of its seniority in the EU, its democratic track-record, the size of its economy and population, and its long experience in diplomacy and foreign affairs. Nor do they necessarily possess the skills of UK statesmen and diplomats, or hold the natural advantage of being native speakers of the English language. This could mean that calls for less integration will have weaker backers. Or, given that even without Brexit, Central and Eastern European states, such as Hungary and Poland, have become more vocal in their resistance to supranational and regulatory EU initiatives, it could mean that anti-EU sentiment persists, but in more statist form, and without a clear articulation that reaches the citizens and political leaders of other Member States. Even though many Europeans are appalled at the British tabloid press, it has offered a language for others elsewhere in the EU to emulate. The national media in Eastern Europe do not reach other Europeans as easily.

Likewise, there are numerous political groupings within Member States, both parties and more diffuse social movements, which reflect popular concern over the deepening of integration in the EU. Without the constraints that UK membership represents, those groups may see an opportunity for further mobilisation of support, resulting from the fear that the EU without the UK could push ahead to integrate further in certain areas. The same arguments used to justify a Leave vote in the UK referendum could also hold sway in other European states (Cini and 
Pérez-Solórzano 2016). Anti-immigration, anti-globalisation and antielite political positions are hardly exclusive to the UK. While Hobolt $(2016,1273)$ argued that there was no evidence of short-term contagion effects, in the sense of other Member States planning on holding referendums, she admits that 'the Brexit vote nonetheless poses a serious challenge to the political establishment across Europe' and that such effects might thus emerge in the months and years ahead.

\section{The centripetal trajectory}

However, without the UK, the EU might be better equipped to move into crisis resolution mode. The Brexit negotiations, if handled well, could help the process of rebuilding solidarity among the EU27. The German government has itself pushed this line (Duff 2017, 1). There is nothing more unifying than having to show a common front. The EU demonstrated this unity early on, during the Bratislava European Council meeting of September 2016, and it was also evident in the run-up to the agreement of the negotiation mandate in April 2017. Indeed, even if relations between the two sides remain relatively cordial, the Member States entering into negotiations with the UK will be aware that the effectiveness of the EU's negotiating strategies will be carefully examined by their own domestic constituencies and that they will need to demonstrate their toughness. The argument often made in the weeks following the UK referendum, that EU Member States will want to ensure the UK does not get too 'good' a deal in order to deter Eurosceptic forces in other Member States' domestic constituencies, still carries some weight - at least in some quarters. The European Council, led by European Council president Donald Tusk and the head of the Brexit taskforce of the Council, Didier Seeuws, is especially important when it comes to bringing the Member States together, since it is responsible for the EU's common negotiating stance (European Council 2017a).

While solidarity has been sorely lacking among the EU Member States in recent years, this has not prevented the emergence of new initiatives. The eurozone crisis has already led to new institutional initiatives, new legislation, a new treaty, and even new institutional mechanisms to deal with the sovereign debt crisis and to prevent further financial meltdown (Verdun 2015). One can easily argue therefore that one of the consequences of the eurozone crisis has been to open the door to further European integration. Brexit may make further steps in this direction even more likely. While the UK neither joined EMU, nor prevented the introduction of the euro, it has since the early 2000s argued vehemently 
for recognition that the EU comprises more than one currency. It has stressed that the EU's (read: eurozone's) policies should not be prejudicial towards Member States using currencies other than the euro. For the UK, this position most often took the form of a defence of the interests of the City of London, and of a more 'facilitative and liberal approach to financial regulation' (Moloney 2017). This matter was of such importance to the UK government after 2010 that it featured as one of the issues dealt with in David Cameron's pre-referendum negotiations. With the UK leaving the EU, and the other EMU 'outs' much weaker, the stage is set for the euro to become, once again, the flagship policy of the EU - and perhaps for further post-crisis steps towards a fiscal (or economic) union. As Sapir et al. put it: 'Brexit also involves opportunities for the EU27. It may generate momentum towards building more integrated and vibrant capital markets that would better serve all its Member States' economies, improve risk sharing to withstand local shocks, and make the Union a more attractive place to do global financial business' (Sapir et al. 2017).

In other policy areas, too, there is some indication of the development of a new pro-integration agenda. Indeed, in the second half of 2016, following the Bratislava European Council in September, France and Germany announced that they were considering strengthening cooperation on security matters. Some might argue that the expected departure of the UK from the Common Security and Defence Policy (CSDP) makes little difference, since the UK has been something of a half-hearted member since at least 2010, and because the North Atlantic Treaty Organization (NATO) is more important for European defence. But from a centripetal perspective, with the UK's departure, the EU loses half of its Franco-British defence axis, which has been at the heart of the CSDP. Thus, in order not to weaken EU defence policy, something needs to be proposed to fill the gap left by the UK. The fact that US President Donald Trump appears less committed to the Western Alliance means that the development of a more robust European defence policy seems more important than before. German leader Angela Merkel seems fully to have grasped this fact, when announcing at the end of the G7 Meeting in late May 2017 that the EU will need to take charge of its own defence (Politico 2017).

Even if these integrative initiatives go ahead, the EU cannot simply return to a business-as-usual approach to integration, but must learn from the experience of Brexit and other EU crises. The March 2017 Commission White Paper on the Future of Europe indicates that there are some important decisions to be made. Without considerable resources (competences, funds) at the EU level, the EU cannot be everything to 
everyone. While it is a system that is based on the rule of law and a large acquis communautaire, the EU is struggling with various Member States that do not always respect the founding principles of the EU. Moreover, the protest votes witnessed in the 2016 Italian referendum, as well as the lessons learnt from Brexit and the election of Trump, indicate that citizens are disgruntled with the way globalisation has treated them (Blockmans \& Weiss 2016, 3).

Yet, with national elections in Western Europe in late 2016 and spring 2017 (Austria, the Netherlands and France) having generated more pro-EU than anti-EU populist leaders, there may be more scope for unity among Member State leaders in the coming months and years. Having had a chance to vote explicitly with European integration in mind, and with more clarity after the UK referendum about the challenges involved in being outside the EU (Financial Times 2017a), there might even be more support from European citizens for deeper European integration. Yet the EU is well advised to ensure that with any deepening comes some sort of increase in democratic accountability to its citizens.

\section{Conclusions}

Brexit is one of several crises to have hit the EU in recent years. The implications of Brexit on European integration are, therefore, also the consequences of those other crises. We view crises as windows of opportunity and sources of motivation for actors who take advantage of instability and uncertainty to push particular agendas. Those agendas are not necessarily pro-integration, in the sense of unconditional transfer of national powers to supranational institutions (supranational integration), but they are associated with EU-level reform. They may, as such, seek to push European integration in a non-supranational direction, by promoting new forms of intergovernmentalism, by institutionalising a multi-speed, differentiated model of European cooperation (Cini \& Pérez-Solórzano 2016), or by further enhancing mechanisms that advance coordination and fine-tuning, as has been the case with social policy coordination (Verdun \& Wood 2013). In his contribution to the Brexit debate, Ferrera (2017) for example makes the case for the establishment of a European Social Union, one that is 'capable of combining domestic and pan-European solidarities'. Alternatively, other agendas pushed by actors in times of crisis may seek to promote disintegration. Actors working for the collapse 
of the EU and a return to exclusively national, or even nationalist, politics will also see crises as an opportunity for them to push their own vision of the future. It remains to be seen which of these competing agendas will be successful. There are no clear indicators as to which agenda will win, as there is no mechanism that will at all times push forward the pro-cooperation agenda. But the political winds that are blowing through the EU27 seem to have produced fertile soil for another attempt at deepening integration. Provided that both the EU and national leaders remain committed to European integration, the event of Brexit may very well mark another bout of centripetal activity, bringing the remaining EU Member States closer together. 